\title{
Political history of Farakka Barrage and its effects on environment in Bangladesh
}

\author{
Mohammad Abul Kawser ${ }^{1 *}$ and Md. Abdus Samad ${ }^{2,3}$
}

\author{
*Correspondence: \\ makawser@du.ac.bd \\ ${ }^{1}$ Department of History, \\ University of Dhaka, Dhaka, \\ Bangladesh \\ Full list of author information \\ is available at the end of the \\ article
}

\begin{abstract}
Soon after the partition of the subcontinent in 1947, India took initiative to construct a barrage on its side of the Ganges and commissioned it in 1975. In the past few decades, many of the 54 Bangladeshi Rivers that originate in India have either been diverted or dammed upstream, inside India. All of these hydro-developmental initiatives have left a profound impact on Bangladesh as it is at the receiving end of the Himalayan fluvial regime. In particular, Bangladesh's agriculture, fisheries, and human health and wellbeing are reported to have been significantly affected by the disruption of natural water flow in its rivers. The debate over the water sharing issues between India and Bangladesh dates back as early as their birth but the historical developments of the disputes have never been adequately addressed in settling the issues. This paper analyzes the political developments in Bangladesh and India over Farakka issue from historical perspectives. It also reveals the adverse effects of Farakka Barrage on environment in Bangladesh. The aim is to provide policy makers with the insights into historical developments of disputes centred on Farakka Barrage to contribute towards better water governance.
\end{abstract}

\section{Background}

Over the past few decades, many of the 54 rivers in Bangladesh that originated in India have been either diverted or dammed upstream, inside India. All of these hydro-developmental initiatives have left a profound impact on the ecology of Bangladesh which is reported to have been significantly affected by the disruption of natural water flow in its rivers. Anthropogenic as well as environmental changes bring pressures on the basin's water resources and the riverine ecosystem itself, presenting unprecedented challenges and potential conflict (Peace Research Institute Oslo (PRIO) 2013: 77). Since its birth, Bangladesh has been in an ever growing disputation over the water sharing issues with India. After commissioning Farakka barrage in 1975, India has been diverting most of the water flow of the river Ganges to her end. As a result Bangladesh is losing a lot of its agricultural and industrial production, fishing and navigation, human health and wellbeing and so on. Changing water flow of the river Ganges has eventually changed the hydraulic character of the rivers and the ecology of Bangladesh. The environmental changes have resulted in the loss of livelihood of a large population in the south-western part of Bangladesh in particular and across the country in general (Swain 1996: 189). The 
affected area is a part of the Ganges-Brahmaputra-Meghna Basin which is among the world's largest and most populated river basins.

No wonder South Asian environmental historians are anxious about policy makers' inability to appreciate the formative historical developments that the natural hydrological system of the Ganges-Brahmaputra-Meghna had promoted before the impact of capitalist modernization was fully felt in the region (Iqbal 2007: 18). Even though politically all seven countries of South Asia have their independent territories, much of the natural resources are shared by two or more political boundaries. Such situation is extremely delicate for flow resources like rivers where demarcation is difficult. The issue becomes important when it comes between in cases like Bangladesh and India since they have been sharing 54 common rivers. Water sharing of the Ganges, the Brahmaputra, and the Meghna could not come to a stable point between Bangladesh and India, despite having a long history of negotiation. A gradual shift has been observed over the years in the definition of environmental issues from an early focus on incorporating environmental and related concerns to a new focus on searching the cause of conflict due to environmental change. It is assumed that this shift is influenced by recent technological development in identifying inherent causes of problem vis-à-vis a growing list of environmental problems and their associated risks to the human beings (Dabelko et al. 2000: 2). This study is an attempt to explore a domain of contestation and cleavages in its encounter with the gradually declining water regime of the plains of today's Bangladesh. Based on documentary evidences it seeks answers to the question of how did the politics in Bangladesh and India develop centering the Farakka issue? How did the construction and commission of Farakka Barrage leave profound effects on the environment in Bangladesh?

\section{Ecological issues in Indo-Bengal politics in the pre-Bangladesh period}

The emergence of ecological controversies between India and Bangladesh can be traced back to the politics during the British colonial period. The idea of diverting water from the east-bound Ganges for West Bengal first surfaced in the early nineteenth century, but in the late colonial period the idea of tampering with the hydrological regime for development projects formed a major part of the modernizing programme of the nation. Meghnad Saha, for instance, envisioned a national project ${ }^{1}$ in line with the Tennessee Valley Authority for the Damodar Valley in West Bengal and advocated similar multipurpose developments elsewhere along India's major rivers. In this context, Saha imagined a national purpose behind all planning (Arnold 2000).

A new form of environmental political economy emerged after the second partition of Bengal in 1947. The political control attained by Bengal's elite class through partition was complicated by the anxiety over losing the ecological heart of the erstwhile Bengal (Iqbal 2010, p. 188). This anxiety resurfaced around the issue of the two nation theory in the attempt to strike a political boundary that would leave Muslim majority Murshidabad in India and Hindu majority Khulna in East Pakistan, in order to secure a hydrologically suitable spot for diverting Ganges water (Chatterji 1999). Murshidabad is important to India as the take off point of Bhagirathi-Hooghly and a considerable stretch of it falls in

${ }^{1}$ The Governor of Bengal appointed a Board of inquiry in 1944 headed by the Maharaja of Burdwan and the noted physicist Dr. Meghnad Saha as member. In their report, the Board suggested the creation of an authority similar to the Tennessee Valley Authority (TVA) of United States of America. 
Murshidabad to coordinate the flow of the Ganges with Bhagirathi. This very partition indicates that the politics played important role in ecology and shaping the border of two post colonial states-India and Pakistan. The genesis of disputes over Ganges water lies there which was aggravated eventually in the course of time.

After the partition, anxieties to sustain West Bengal's agriculture and economy culminated in the construction of a barrage on the river Ganges. The then Maharaja of Cossimbazar, Srischandra Nandy noted that.

Our position as regards food production has been dangerously affected due to the major paddy-growing areas being made over to Eastern Bengal. In short, as a result of partition there is now the sad legacy of less food but more to be fed (Nandy 1948).

For Nandy, the slogan was to produce or to perish, a dilemma that was to be addressed by an improved river system. To him, the scheme of a barrage across the Ganges was perhaps the only effective means of inducing a plentiful supply of fresh up-land water down through the Bhagirathi, the Hooghly and other dead and dying spill-channels in central Bengal. To him this was the surest way "not only to put new life into the moribund countryside, but also to maintain the efficiency of the Port of Calcutta which has assumed a vital significance to us after the partition of Bengal" (Nandy 1948).

The foremost objective behind construction of the Farakka Barrage was reiterated in the government documents in India was only and exclusively the preservation and maintenance of the Calcutta port and the water regime and navigability of Bhagirathi-Hooghly River (Government of India 1982). Calcutta port is one of the primary ports of India, serving not only the Indian states of West Bengal, Bihar, Orissa, Assam and partly Uttar Pradesh but is also vital to the overseas trade of India, Nepal and Bhutan. A number of minerals, metals, beverages, wood-based, food processing, leather, jute and chemical industries are dependent on this part. However, over the years the pre-eminent position of Calcutta port has declined due to progressive deterioration of head water supply of Bhagirathi-Hooghly. The decreased water flow created problem of siltation which has resulted in frequent occurrence of tidal bores. ${ }^{2}$ This led to overall reduction in navigability. Besides, the decline of traffic in the Calcutta port took place despite rapid industrialization of Eastern hinterland since independence in 1947 (Government of India 1975). India opined that all the studies conducted in regard to safety of Calcutta port beginning from mid-nineteenth century came to the identical conclusion that the safety of Calcutta port is dependent upon increase in the headwater supply through diversion of water by means of a barrage (Government of India 1975).

Preliminary planning for Farakka Barrage in India had commenced way back in 195051, when Bangladesh was still a part of Pakistan. At that juncture Pakistan had expressed concerns on the possible effects of the Farakka Barrage on East Pakistan. In the initial stage India did not take Pakistan's objections seriously pointing out that the project was only under primary investigation and termed Pakistan's concern over the probable effects as purely hypothetical (Abbas 1982). At the same time India carried on her project planning. Pakistan requested India to consult her prior to operation of any scheme which would have adverse effect on East Pakistan. In 1953, India proposed that the two

2 Tidal bore is the sudden rise of huge water, about one or two meters high which rushes up a river at tremendous speed and exposes ships to danger of capsizing and twists and uproots jetties. 
countries should collaborate in the development of Ganges water resources. In the following year, Pakistan threw an outline of Ganga-Kobadak (GK) project in East Pakistan including a proposal for irrigating two million acres of land requiring a maximum of 2000 cusecs of water and joint survey of upper reaches of Ganges and Brahmaputra but India refused this outline. The two governments, however, agreed to exchange available data in respect of projects of mutual interest and to conduct meeting of experts on both sides. Accordingly, there were five meetings of experts in 1960-62 and again in 1968-69 as there was an interlude due to India Pakistan war 1965. Pakistan proposed that they should avail of technical and advisory services of the United Nations but India turned it down. At the secretary level talks in 1969, Pakistan raised her voice for a package deal guaranteeing fixed amount of water to East Pakistan and prescribed a mechanism for the implementation and supervision of the agreement (Hossain 1981: 1120).

India, however, refused to arrive at any decision until exchange of data and agreement on basic technical facts. The last meeting between India and Pakistan at secretary level was held in 16-17 July 1970 in New Delhi. It was agreed that the point of delivery of water into East Pakistan would be at Farakka and that a body consisting of one representative of each country would be constituted to ensure delivery of water, the amount of which was to be decided on later. The decision reached at this meeting could not be implemented as domestic turmoil engulfed Pakistan resulting in the birth of Bangladesh. Thus, in spite of exchange of data and meetings between India and Pakistan, no agreement was reached regarding water sharing of the river Ganges. Pakistan was preoccupied with the Kashmir question and was not serious enough to push through an agreement on sharing of Ganges waters similar to Indus Basin Treaty between India and Pakistan. India was also reluctant and she was "following a strategy of procrastination during this period, which denied Pakistan any influence in the design or construction of Farakka Barrage" (Crow 1980).The Farakka barrage that India started constructing in 1962, was completed in 1970 at a cost of \$208 million. With a 75 feet high and 7000 feet long barrage, a 26.5-mile-long feeder canal into the Bhagirathi River was added that took another 4 years to complete (Hossain 1981: 1119).

Thus, India was successful in persuading British colonial rulers regarding the border between India and Pakistan considering the ecologically strategic points. This initial success of India gave her an upper hand in negotiating with Pakistan during post colonial era. Agricultural and economic needs of India pushed her towards the construction of Farakka Barrage ignoring Pakistan's continuous protest. The political developments of this period reveals that the emergence of nation states in South Asia during post-colonial period drew lines of demarcation on the common rivers according to the borders of those nation states. It developed a sense of individual ownership instead of collective ownership over the common rivers which can be identified as one of the major reasons behind using these rivers at the cost of the interests of co-riparian states. Internal turmoil in Pakistan reduced its negotiating capability regarding water sharing issues with India. Moreover, India-Pakistan War in 1965 hampered the process of negotiations.

\section{Birth of Bangladesh and the Farakka tangle}

In the prevailing atmosphere of utmost enthusiasm and cordiality that defined Bangladesh's relations with India in 1971, it was expected that the water sharing dispute would 
be resolved to the mutual advantage of both the neighbours. A breakthrough was made in the initial years but it was short-lived and the relations grew more strenuous in the years to come. The formation of a government in Bangladesh by the Awami League brought about new hopes for a settlement of the Farakka issue. In place of Pakistan, India now faced a friendly but weak Bangladesh across the negotiating table. Both governments felt that the Ganges water dispute could be approached from the perspective of the vast opportunities for comprehensive development of the region's water resources in the interests of the peoples of both India and Bangladesh (Hossain 1981: 1113).

In March 1972, a Joint Declaration was signed between Sheikh Mujibur Rahman and Indira Gandhi. On the basis of this Declaration, a Joint River Commission (JRC) was formed in 1972. This Commission conducted joint aerial hydrographical surveys, joint survey of embankments on common rivers on both sides boundary to identify weak points which could be strengthened and gaps which could be closed by further embankments. Bangladesh had reconciled herself to the existence of the Farakka Barrage. Of importance now was the sharing of the Ganges waters. During Sheikh Mujibur Rahman's visit to India in May 1974, India agreed to commission the Farakka barrage only after an accord was reached on sharing of dry season flow of the Ganges. A temporary arrangement for allocation of Ganges waters was made following an agreement signed on 18 April 1975 (Gulati 1985) (Table 1).

This agreement was hailed as an outstanding example of mutual understanding and accommodation. It was signed on a trial basis. India withdrew water in the lean season of 1975 in terms of the agreements and remaining flew to Bangladesh. Indian share was significantly lower than her requirement that proves her political will at this stage. India's share varied between 20 per cent in first 10 days period and 24.43 per cent in last 10 days period whereas Bangladesh ranged between 80 and 75.57 per cent in the same period. It is clear that it was India's gesture of goodwill that led to a tentative solution of the dispute. However, with the overthrow of the government of Bangladesh in 1975, India hardened her attitude towards Bangladesh (Peace Research Institute Oslo (PRIO) 2013). The friendly Mujib government was perhaps the best option for India to secure her interest in Bangladesh. Eventually, the ecologically important water issues for both Bangladesh and India got a political flavour with the hand of Indian government immediately after the fall of Sheikh Mujib.

This arrangement expired on 31 May 1975, and until it was replaced by another agreement in 1977, India unilaterally withdrew water (40,000 cusecs) at Farakka that led to a controversy. Bangladesh desired an equitable sharing of water and regarded the Indian

Table 1 Sharing of lean season flow at Farakka, India-Bangladesh water sharing agreement 1975 (amount to be shared in cusecs) (Gulati 1985)

\begin{tabular}{llll}
\hline 10 day period & $\begin{array}{l}\text { Dependable } \\
\text { supplies at Farakka }\end{array}$ & $\begin{array}{l}\text { Amount agreed } \\
\text { upon for Hooghly }\end{array}$ & $\begin{array}{l}\text { Remaining flows } \\
\text { for Bangladesh }\end{array}$ \\
\hline 21 April-30 April 1975 & 55,000 & 11,000 & 44,000 \\
1 May-10 May 1975 & 56,500 & 12,000 & 44,500 \\
11 May-20 May 1975 & 59,250 & 15,000 & 44,250 \\
21 May-31 May 1975 & 65,500 & 16,000 & 49,500 \\
\hline
\end{tabular}

Source: Government of Bangladesh, 1975 
action as breach of agreement. Throughout 1976-77, India withdrew water on her own decision. In response to complaint of Bangladesh, India complained that in spite of specific provision in 1975 agreement, government of Bangladesh did not fully cooperate in compiling data and information needed to finalize the joint assessment of the effects of withdrawal at Farakka (Government of India 1975).

Bangladesh assailed India for diversion of water which caused her severe hardships. Both at the national and international level, Bangladesh displayed widespread resentment against withdrawal of water by India. Bangladeshi leader, Maulana Abdul Hamid Khan Bhasani sought to mobilise public opinion on alleged devastating desertification caused by reduced flow of Ganges that was created by India. Nationalist leader Bhasani threatened to lead a long march to demolish Farakka on which depended survival of about three and a half crores of people of northern and south-western Bangladesh. He even exchanged letters with the then Prime Minister of India, Indira Gandhi and appealed to her to.

Personally intervene and work out a solution yourself, which could be acceptable to Bangladesh. If this was not done, I shall be compelled to follow the path of struggle I have learnt from your forefathers and Mahatma Gandhi (Asian Recorder 1976).

India argued that Farakka barrage was the only means of saving Calcutta port and hence could not be abandoned; but in a spirit of mutual understanding and cooperation shortfalls in the water flow could be made up. Indira Gandhi stressed that India had maintained the flow into Bangladesh by denying even minimum quantity of water required to flush Hooghly. She reiterated that, "India was open to persuasion and reasoned argument but no one should expect India to submit to threats and palpably unreasonable and unjustified demands" (Asian Recorder 1976). Maulana Bhasani launched the Farakka Long March on May 16, 1976 to draw the attention of people of India towards demands of people of Bangladesh on sharing of waters. However, both the governments were vigilant to prevent any possible danger to the barrage. It was evident that the government of Bangladesh was concerned with maintaining good relations with India and at the same time was trying to mobilise a public support to make India understand the potential ecological and economic danger of Farakka barrage in Bangladesh. Although a popular resentment was concentrated among the common people of Bangladesh, the post Mujib government followed the way of peaceful solution of the Farakka issue with India.

Since India had turned hostile and was also trying to destabilise the Zia regime, Bangladesh required world support. Bangladesh raised the issue in international forums to gather world sympathy and possibly to earn legitimacy for the military government. With the change of government in India with Desai at the helm, the relation between Bangladesh and India considerably improved. India agreed that support extended by previous government to guerrillas to destabilize Zia regime would be snapped. India refrained from aiding the pro-Mujib guerrillas in India, to see that no shelter was given to criminal elements from across the border (The Hindu 1977). Despite the elimination of hostility, not much progress was seen regarding the Farakka issue. In May 1976, Bangladesh raised the issue at the Islamic Foreign Ministers Conference at Istanbul and at the 31st session of United Nations General Assembly. 
The Indian side, however, took the view that the problem was a bilateral one and any attempt to internationalise it would only complicate the situation, delay solution and worsen their relations. India urged the General Assembly that she wished to develop friendly relations with Bangladesh on the basis of equality to mutual benefit but the discussion of this question at United Nations would only lead to complications. Despite bickering in the world body, the issue remained unresolved as only a census statement emerged after a discussion. From the UN General meeting both India and Bangladesh decided to meet urgently in Dacca with a view to arriving at a fair and expeditious settlement on Ganges water sharing at Farakka point (UN General Assembly 1976).

This section suggests that good relationship between Bangladesh and India during Mujib-Indira governments played positive role in resolving the disputes over water sharing of the river Ganges. But changes in the government in Bangladesh impacted upon the water governance of the river Ganges as the governments lacked mutual understanding on Farakka issue. Observing no progress at government levels, a popular movement was mobilized in Bangladesh by Bhasani which led to a long march upholding the demand of equitable share of water of the River Ganges. Bhasani's movement played an important role in bringing the two governments to the negotiating table. This section also indicates that the efforts towards internationalization of the issue by Bangladesh could not earn much in terms of getting any solution from the international community. It, however, could bring India into the negotiations. As a result water sharing agreements of 1977 and memorandum of understandings (MoU) between India and Bangladesh were signed.

\section{The 1977 agreement: an initial stage of Indo-Bangladesh water sharing treaty}

After protracted negotiations India and Bangladesh formally entered into an agreement on 5 November 1977 devising a formula for sharing dry season flow of water. The then President of Bangladesh Ziaur Rahman played the vital role in materialising the agreement. This agreement was completely bilateral in nature and it laid down that any differences in its interpretation would also be solved bilaterally. It was a landmark in the relations of the two neighbouring countries. This occurred when President Ziaur Rahman in Bangladesh was striving to provide stability and development to Bangladesh and fostered South Asian Regional Cooperation (SAARC). India was also striving to give new directions to foreign policy in terms of promoting friendly relations with all, especially with neighbours.

The agreement signed for 5 years offered only partial solution as it only decided the sharing of lean period flow. The short term aspect of the agreement fixed the quantum of water from the flow of Ganges at Farakka for the two sides during 5 months period from January to May every year. As a long term solution, it referred to augmentation of flow of Ganges waters (Government of India 1977). The share of India ranged 40.7 per cent between January 1-10 and 37 per cent in the leanest period between April 21-30 and that of Bangladesh between 50.4 and 52.8 per cent respectively in the same period. Bangladesh was guaranteed a minimum quantity of water in each 10 day period of lean season irrespective of the discharge available at Farakka (Government of India 1977).

The government of West Bengal vitally concerned with the safety of Calcutta port criticised the agreement for not allocating to India sufficient quantity of water. It was pointed out that Farakka barrage was constructed for safety of Calcutta port which is 
the life line of the entire eastern region but if the port was devoid of minimum water required there was no justification of construction of Farakka barrage at the cost of Rs. 156 crores. In his letter to the Prime Minister of India, the Chief Minister of West Bengal, Jyoti Basu emphasized that 40,000 cusecs was the minimum required in the months.

I hope you will take steps to ensure this flow... West Bengal is also very much concerned at the stalemate on augmentation of flow at Farakka which is of paramount importance for meeting the ultimate requirements of India and Bangladesh. This augmentation is essentially necessary to meet the growing demand for rabi irrigation in the districts of Murshidabad, Nadia and 24 Pargana and parts of Burdwan and Hooghly districts (Government of West Bengal 1981).

The agreement signed in 1977 expired on May 30, 1982. During this period attempts were made both at signing a renewed agreement and acceptance of proposals on water sharing and augmentation but there was little progress. The summit meets between General Ershad, Chief Martial Law Administrator of Bangladesh and Mrs. Gandhi the Prime Minister of India in October 1982 was hailed as opening of a new horizon in their relationship. The two leaders had underlined the need for promotion of friendly relations and cooperation between the two countries. The net effect of this meeting was the extension of 1977 agreement with minor changes for two more dry seasons. It was also decided that within 18 months the two sides would reach an agreement on augmentation after conducting prefeasibility studies although it did not come true. Indo-Bangladesh water sharing issue could only reach to some MoUs in the decade of 1980s.

\section{Memorandum of understanding (MoU) 1982 and 1985}

The minimum guarantee of water to Bangladesh ensured in 1977 agreement was removed in the MoU signed in 1982. It recognized that the basic problem of inadequate flow of water in Ganges available at Farakka imposed concessions on both the countries. It agreed that long term solution lay in increase of flow at Farakka. It was decided that JRC would complete the economic and technical prefeasibility study of schemes of either side after which the two governments would implement the augmentation proposals. As a result, a temporary measure of water sharing schedule was agreed upon (IndiaBangladesh Water Sharing Agreement 1982). The $1982 \mathrm{MoU}$ continued until 1984 and another MoU was signed in 1985.

The1985 MoU provided the sharing of the Ganges river water during the lean season for the next 3 years, i.e., 1986-88, with the provision for functioning out a scheme to augment the flow through a joint study within a duration of 1 year (The Indo-Bangladesh MoU 1985). The two governments agreed that if the available flow specified for the corresponding 10 days period, then the share of Bangladesh would be calculated at the prorata basis at 75 per cent and above of the available flow and would be regarded as the burden which was to be equally shared by both the countries. In case of any exceptionally low flow, the nest release of Bangladesh would be the pro-rata share at actual available flow, i.e., below 75 plus 50 per cent of the burden shared by India. The agreement provided for setting up a Joint Committee consisting of an equal number of representatives nominated by the two countries to evolve a long term solution for the augmentation of water flow of Ganges during the lean season (The Indo-Bangladesh MoU 1985). 
The above two sections indicate that after the fall of Mujib government, India and Bangladesh could not reach to a long-term solution regarding the water sharing of the River Ganges. The absence of friendly governments can be identified as one of the major causes behind this little progress. In addition, Government of West Bengal put a pressure on central government raising the economic issues related to water sharing at Farakka point. During this period, India only signed an agreement and a couple of MoUs to maintain a working relationship with Bangladesh.

\section{Unilateral water withdrawal by India and Ganges water sharing treaty 1996}

After the expiry of $1985 \mathrm{MoU}$, India unilaterally continued to withdraw water at Farakka in 1988-91, to save the Calcutta port from silting. This unilateral withdrawal was again criticised from Bangladesh's side and Bangladesh demanded a permanent solution to the problem. The Indian Minister for External Affairs, I. K. Gujral visited Dhaka in February 1990 and both the countries agreed to reactivate the JRC to suggest solution of the water problem. In April and June 1990, two meetings were held and several important decisions were taken but the permanent water sharing solution was still a far cry. In April 1992 a meeting was held in Dhaka that discussed the recommendations of JRC but no concrete step was taken on sharing the Ganges water.

Bangladesh Premier Khaleda Zia and her Indian counterpart Narasimha Rao met on 27 May 1992 in New Delhi and agreed on formulating a permanent and comprehensive plan on sharing the Ganges water resources. Their desire to solve the major bilateral disputes in the spirit of cooperation and friendship and strengthening of bilateral relations was emphasized in the meeting. The meeting had no conclusive results and India continued to withdraw waters unilaterally. Particularly after the year of 1988 India insisted on unilateral withdrawal of waters at Farakka. Getting no response from the Indian side to solve this water-sharing problem, Bangladesh started to internationalize the Ganges water issue.

Finally in 1993 Bangladesh put the issue before the United Nations General Assembly and the Commonwealth Heads of Governments Meeting, which had very paradoxically made the probability of success in bilateral negotiations limited as India always considered the issue bilateral (Swain 1996: 199). In the year between 1989 and 1996, India did not extend the previous agreement and even there was no new water sharing deal with Bangladesh.

Situation changed with the change of the government in Bangladesh. New government of Bangladesh started negotiating with India for a new treaty. A thirty-year water sharing treaty was signed in 1996 between the two countries. The Treaty was an important manifestation of the disposition between India and Bangladesh. They tried to find a mutually acceptable solution to the deadlock for some decades. Supposedly the treaty got recognition of a landmark in the ongoing tension on water sharing politics in this region. The development of sharing Ganges waters which had been regarded as a competitive zero sum game between the two countries, got its hallmark in the Pakistan period, continued after the Farakka Barrage was activated on 21 April 1975 and provided a useful insight into what both sides found acceptable as a compromise with treaty of 1996 (BrichieriColombi and Bradnock 2003). 
The Treaty sets out for each country the share of the incoming flows it will receive in each 10 day period between 1 January and 31 May each year. The flows are measured in cusecs at Farakka, and almost all India's share is diverted down the Feeder Canal to the Bhagirathi-Hooghly, a mere 200 cusecs being reserved for use in India downstream of Farakka. The sharing arrangement covers flows in three stages, the highest Indian diversion being 40,000 cusecs, equal to the capacity of the Feeder Canal. Under the Treaty India may divert this flow when the incoming flow is 75,000 cusecs, leaving 35,000 cusecs for Bangladesh. The permitted diversion is reduced gradually as the incoming flow reduces to 70,000 cusecs and below that the flows are shared equally. This flow of 70,000 cusecs is exceeded 60 per cent of the time in the dry season, based on the 1949-88 measurements of flows arriving at Farakka. Thus for 40 per cent of the dry season period covered by the treaty, the flows are shared equally (Brichieri-Colombi and Bradnock 2003). If the flow falls below 50,000 cusecs, the two Governments will enter into immediate consultations to make adjustments on an emergency basis, in accordance with the principles of equity, fair play and no harm to either party (Bangladesh India Water Sharing Treaty 1996). The water-sharing agreement was the first success in a series of foreign policy initiatives undertaken by the then Awami League government to improve relations with India.

The above section shows that how the changes in governments impact negotiations over water issues. In the early 1990s, Bangladesh Nationalist Party (BNP), popularly known as anti-Indian political party in Bangladeshi politics, formed the government and started negotiations with India to get equitable share of Ganges water but failed to reach to solution. Like post-Mujib governments, BNP also tried to internationalize the issue and did not succeed. So in the context of politics within and between Bangladesh and India, it can be argued that when two less friendly governments are in the power, negotiations over water sharing issues seemed to be stagnant. Finding no hope from bilateral negotiations Bangladesh being the lower riparian state tried to internationalize the issue to get the equitable water share of the River Ganges but failed. The situation changed when Bangladesh Awami League, popularly known as friendly to India, assumed power in 1996. Finally, a thirty-year treaty was signed between two countries regarding water sharing of the River Ganges. It reiterates our previous argument that friendly relationship between the governments is very important in reaching any solution regarding water issues. Although this treaty put an end to the long drawn negotiations between Bangladesh and India since the erection of Farakka Barrage, it failed to minimize the impact of the Barrage on the ecology of Bangladesh as the flow of water at Farakka is gradually decreasing due to upstream water withdrawal.

\section{Environmental Impact of Farakka Barrage on Bangladesh}

Bangladesh is sensitive to diversion of Ganges water through Farakka barrage which adversely affected her ecology and economy. 37 per cent of the total area and 33 per cent of the total population of Bangladesh is dependent on Ganges basin (Hossain 1981). As a result of reduced flow of Ganges, Bangladesh has faced problem in the field of agriculture, industry, fisheries, navigation, salinity and ecology, etc., in the south western region. About one-third of the total area of Bangladesh is directly dependent on the Ganges basin for their livelihood. In these circumstances water diversion at Farakka 
is bound to have an impact as it was an attempt to introduce a new ecological system against the usual course of nature. A substantial number of studies compared the pre and post Farakka situations in Bangladesh. According to these studies, there is a huge contrast between pre and post Farakka water supply, where the situation was much better in pre-Farakka period even in dry season in the downstream, more particularly in the Bangladesh part (Mirza and Hossian 2000). It was expected that situation would improve after the treaty but a substantial amount of studies showed that the situation has become even worser in some cases.

The water scarcity has brought much misery and hardship to the people of the affected south-western parts of Bangladesh that has resulted disruption of fishing and navigation, brought unwanted salt deposits into rich farming soil, adversely affected agricultural and industrial production, changed the hydraulic character of the rivers and brought about changes in the ecology of the Delta. Due to the Ganges diversion the minimum discharge of the river Padma at the point of Hardinge Bridge in Bangladesh fell far below. The groundwater level in the highly affected area went down particularly in the district of Rajshahi, Kustia, Khulna and Jessore. The southwest region had been facing the critical problem of salinity intrusion from the Bay of Bengal because of the drastic reduction of fresh water flows in the Gorai river which is the major distributary of the Ganges in this part of the country (Tiwary 2006).

The ever decreasing dry-season flow has aggravated the excessive river bed situation on the Bangladesh side which has been instrumental in increasing the number of devastating monsoon floods in flood-prone Bangladesh. A southern district of Bangladesh, Patuakhali which is commonly known as the daughter of the sea comes under the Ganges-dependent basin area. This entire area has been very seriously affected by river bank erosion and some of its adjacent areas are on the verge of extinction. The increased salinity of the river water has forced several industries to close down which has affected domestic water supply and resulted in the large scale damage of trees of the natural mangrove forest in the south-western part of Bangladesh (Swain 1996); Tiwary 2006. Hundreds and thousands of farmers have become landless in some of the districts of the same region in the country. Barguna is one of those districts where the river bank erosion played the key role in making some 50 per cent of the farmers landless. The ecological and environmental destruction created by Farakka has led to an irreparable loss of agriculture, fishing, forestry and ecosystem of Bangladesh. A significant part of Rajshahi division and the whole of Khulna division are under the same threat. Because of the stagnant agriculture, closure of industries and navigation facilities, a drop in fish yields, the death of valuable forest resources, the disappearance of land due to river-bank erosion, the socio-economic condition of the above mentioned regions have also become quite vulnerable along with the environmental degradation (Hossain 1998).

The following table shows a devastating scenario in terms of financial and environmental loss in Bangladesh after the Farakka operation. The JRC Bangladesh chapter estimated that the economic loss of Bangladesh from 1976 to 1993 due to Farakka water withdrawal is Tk. 113,240 million which is nearly US\$3 billion. This loss even excludes the losses Bangladesh has incurred because of floods and river bank erosion which has become a regular phenomenon in the country (Table 2). 
Table 2 Economic losses due to environmental disaster aggravated with the construction of Farakka Barrage, 1976-1993 (Swain 1996)

\begin{tabular}{ll}
\hline Items & $\begin{array}{l}\text { Financial loss in million } \\
\text { taka (1991 price index) }\end{array}$ \\
\hline Agriculture & 37,000 \\
Fisheries & 63,000 \\
Forestry & 9900 \\
Industry & 1150 \\
Public health & 1180 \\
Navigation & 560 \\
Dredging & 560 \\
GK intake channel and Gorai off take channel & 450 \\
Total & 113,240 (nearly US\$3 billion) \\
\hline
\end{tabular}

Source: Indo-Bangladesh Joint River Commission, Dhaka, Bangladesh

Immediately after the Water Sharing Treaty of 1996 it was discovered that the flow of the Ganges River at Farakka was far less than anticipated in the treaty. The water released to Bangladesh in 1997 and 1998 was less than the quantity fixed by the treaty (Peace Research Institute Oslo (PRIO) 2013: 77). The Ganges Water Treaty of 1996 was supposed to bring a long-term solution to the problem of Ganges water-sharing between India and Bangladesh. But the reality never sounds sweet in the context of the IndoBangladesh water sharing issues where the question of ecological sustenance of Bangladesh is closely related. Several factors raise doubts about the sustainability of the Ganges Water Treaty provisions in the medium to long term. The Ganges Water Treaty states that 'Every effort would be made by the upper riparian to protect flows of water at Farakka as in the 40-years average availability as mentioned above' (Bangladesh India Water Sharing Treaty 1996). Besides, the treaty has a provision for review, but unfortunately is, neither of the sides has ever called for this.

Due to the effect of freshwater withdrawals at Farakka the over-exploitation of fishing and forestry resources is a widespread problem in Bangladesh in the post 1996 period. The water table levels in the dry season have become lower everywhere in the country. In this case the groundwater is being used over there and as a result the navigation depths are reducing due to polder construction in many rivers. In the true sense almost every problem in the country associated with water has been attributed to the impact of Farakka (Brichieri-Colombi and Bradnock 2003). This is discernible that the very social, economic and environmental problems have become part and parcel to the Bangladeshi people which are gradually accelerated due to withdrawals of Ganges waters at Farakka. The Farakka barrage could be very rightly marked as a stalemate in water development in such a part of South Asia which is inhabited by some one-fifth of the world's total population.

\section{Conclusion}

In an environmentally interdependent world the environmental or ecological decline of one country or region is a problem for the entire community of nations on earth. With the emergence of post-colonial nation states, an array of demarcation lines was drawn on the common rivers according to the borders of newly established states. It developed 
a sense of individual ownership instead of collective ownership of the common rivers. Rivers were no longer being considered as an integrated unit of resources. Upper riparian states started to use common rivers to the end of their own interests at the cost of the interests of the lower riparian states. And this can be identified as one of the major reasons that created problems among the co-riparian states around the world.

A peaceful internal political atmosphere and a sound relationship among the co-riparian states act as the successful catalyst of bilateral negotiations that create an environment of peaceful coexistence and helps growing an attitude of sharing water resources of the common rivers. Absence of such friendly atmosphere between the states might lead to a popular movement in the lower riparian state if deprived by the unilateral water withdrawal by the upper riparian state. This situation might also lead lower riparian state towards internationalization of the issue though it often does not earn much for the lower riparian state if the upper riparian state insists on bilateral solutions. A kind of cooperation is possible for a common interest for the countries concerned if the bilateral negotiations are tuned up. It is important for the policy makers of both the countries to critically analyze how bilateral negotiations and their results reflect on the internal political and economic dynamics.

This paper suggests that water governance and management is significantly influenced by the internal political economy of both the countries involved. So it is important to consider historical development of political economy of both countries to reach an amiable solution over water sharing of the River Ganges. As the flow of this river passes not only between West Bengal and Bangladesh, problem of water sharing cannot be solved until and unless the economic interests of other co riparian provinces of India are brought into the negotiation process because they are also diverting water from this river. It is also important to consider the whole river as an integrated unit to solve the ecological problems created by the basin states.

\section{Authors' contributions}

MAK: formulating research questions, interpretation of historical data and conclusion. AS: collecting documents, sequencing chronologically and developing arguments. Both authors read and approved the final manuscript.

\section{Author details}

${ }^{1}$ Department of History, University of Dhaka, Dhaka, Bangladesh. ${ }^{2}$ Department of History, Jagannath University, Dhaka, Bangladesh. ${ }^{3}$ Department of History and Culture, Jamia Millia Islamia, New Delhi, India.

Competing interests

The authors declare that they have no competing interests.

Received: 17 December 2015 Accepted: 17 December 2015

Published online: 04 January 2016

\section{References}

Abbas, BM. 1982. The Ganges waters dispute. Vikash. New Delhi.

Arnold, D. 2000. Science, technology and medicine in colonial India. Cambridge: Cambridge University Press.

Brichieri-Colombi, S., and R.W. Bradnock. 2003. Geopolitics, water and development in South Asia: cooperative development in the Ganges Brahmaputra Delta. Royal Geographic Society with IBG 169(1): 43-64.

Chatterji, J. 1999. The fashioning of a frontier: the radcliffe line and Bengal's border landscape 1947-52. Modern Asian Studies 33(1): 185-242.

Crow, B. 1980. Politics and stagnation in the Rivers of South Asia: why are Ganges and Brahmaputra undeveloped?. Edinburg: Edinburg University Press.

Dabelko, G.D., H. Mark, S. Lonergan, and R. Matthew. 2000. State-of-the-art review on environment, security and development co-operation, prepared for the working party on development, cooperation and environment. Paris: OECD Development Assistance Committee.

The Farakka Barrage, XP Division, Ministry of external affairs, Government of India, New Delhi. 
The Agreement between the Government of Republic of India and the Government of People's Republic of Bangladesh on sharing of the Ganges waters at Farakka and on augmentation of its flows. Ministry of energy, Government of India, New Delhi.

Performance budget. Ministry of irrigation, Government of India, New Delhi.

India-Bangladesh water sharing agreement 1982. Ministry of external affairs, Government of India, New Delhi.

Chief Minister's letters to the central Government: a selection, department of information and cultural affairs, government of West Bengal, Kolkata.

The Bangladesh-India treaty on sharing the waters of the Ganges River. Ministry of external affairs, Government of India, New Delhi.

Gulati, C. 1985. Indo- Bangladesh Relations. An Unpublished PhD Thesis.Jamia Millia Islamia, New Delhi.

Hossain, I. 1981. Bangladesh-India relations, issues and problems. Asian Survey 21(11): 1115-1128.

Hossain, I. 1998. Bangladesh-India relations: the Ganga water sharing treaty and beyond. Asian Affairs 25(3): 131-150.

labal, I. 2007. Making sense of water. Forum 2(5): 18-19.

lqbal, I. 2010. The Bengal delta. ecology, state and social change 1840-1940. Palgrave Macmillan, Basingstoke and New York. Mirza, M., and M. Hossian. 2000. Adverse effects on agriculture in the Ganges basin in Bangladesh. In The Ganges water diversion: environmental effects and implications, ed. M.Q. Mirza. Netherlands: Kluwer Academic Publishers.

Nandy, S. 1948. Preface, Bengal Rivers and our economic welfare. Calcutta: The Book Company Limited.

Peace Research Institute Oslo (PRIO). 2013. Water Scarcity in Bangladesh. Oslo, PRIO.Qureshi, S. 1995. Indo-Bangladesh Relations. An Unpublished PhD Thesis. Jamia Millia Islamia, New Delhi.

Exchange of letters on sharing of Ganges River waters with India, Asian Recorder 22(23): 13189.

Swain, 1996. Displacing the conflict: environmental destruction in Bangladesh and ethnic conflict in India. Journal of Peace Research 33(2): 189-204.

The Hindu. 1977. India-Bangladesh water sharing agreement signed. June 11.

The Indo-Bangladesh memorandum of understanding. Ministry of external affairs. New Delhi.

Tiwary, R. 2006. Conflicts over International waters. Economic and Political Weekly 41(17): 1684-1692.

31st session of United Nations General Assembly. Special Political Committee, Agenda item 121, 15 November.

\section{Submit your manuscript to a SpringerOpen ${ }^{\circ}$ journal and benefit from:}

- Convenient online submission

- Rigorous peer review

- Immediate publication on acceptance

- Open access: articles freely available online

- High visibility within the field

Retaining the copyright to your article

Submit your next manuscript at $\$$ springeropen.com 